\title{
Quality characteristics, antioxidant activity and storage properties of fermented milk added with green tea powder
}

\author{
Su-bin $\mathrm{Yeo}^{1}$, Soo-Hwan Yeo ${ }^{2}$, Heui-Dong Park ${ }^{1,3 *}$ \\ ${ }^{1}$ Department of Food Science and Biotechnology, Kyungpook National University, Daegu 41566, Korea \\ ${ }^{2}$ Fermented Food Science Division, Department of Agro-Food Resources, NIAS, RDA, Wanju 55365, Korea \\ ${ }^{3}$ Institute of Fermentation Biotechnology, Kyungpook National University, Daegu 41566, Korea
}

\section{녹차가루 첨가 발효유의 이화학적 특성과 항산화활성 및 저장성평가}

\author{
여수빈 ${ }^{1} \cdot$ 여수환 ${ }^{2} \cdot$ 박희동 ${ }^{1,3 *}$ \\ ${ }^{1}$ 경북대학교 식품공학부 식품생물공학전공, ${ }^{2}$ 농촌진흥청 국립농업과학원 농식품자원부, \\ ${ }^{3}$ 경북대학교 발효생물공학연구소
}

\begin{abstract}
With the goal of developing a new functional fermentation milk using green tea powder (GP), milk was fermented with direct vat set (DVS) starter culture containing Streptococcus salivarius subsp. thermophilus, Lactobacillus paracasei and $L$ delbrueckii subsp. bulgaricus. We investigated fermentation characteristics and antioxidative activities of fermented milk supplemented with different concentrations (0.5, 1, 2, 3\%) of GP. All samples were evaluated for $\mathrm{pH}$, total acidity, viable cell count, and sugar contents. The $\mathrm{pH}$ of all samples decreased during fermentation, and the final $\mathrm{pH}$ ranged from 4.35 to 4.51 . The acidity increased during fermentation, after the fermentation was completed, the titratable acidity was 0.8 to $1.1 \%$. And viable cell count of all samples increased during fermentation, and the final viable cell count was 8.57 to $8.89 \log \mathrm{CFU} / \mathrm{mL}$. The sugar content decreased as the fermentation proceeded and finally reached 12 to $13{ }^{\circ}$ Brix. And increasing GP, decreased brightness and increased yellowness. Increasing GP concentration added to milk, improved DPPH free radical scavenging activity and ferric ion reducing activity of fermentation milk. The fermentation milk kept their $\mathrm{pH}$, total acidity and viable cell counts standard of fermentation milk during the storage period at $4{ }^{\circ} \mathrm{C}$. These findings confirmed the possibility of development of the novel functional fermentation milk through the investigation of the quality characteristics of the fermentation milk added with GP.
\end{abstract}

Key words : green tea powder, fermented milk, physicochemical property, quality characteristics, antioxidant activity

\section{서 론}

고령화사회가 됨에 따라 건강에 유익한 기능성 식품과 관련된 소비자들의 관심이 증가하고 있다. 이로 인해 장내 유해균을 억제하고 건강에 유익한 작용을 하는 살아있는

*Corresponding author. E-mail : hpark@knu.ac.kr Phone : 82-53-950-5774, Fax : 82-53-950-6772

Received 27 June 2017; Revised 4 August 2017; Accepted 10 August 2017.

Copyright (c) The Korean Society of Food Preservation. All rights reserved.
비병원성균주인 probiotics(1)와 그 영양원인 prebiotics가 합쳐진 synbiotics가 주목을 받고 있으며, 발효유는 소비자 들이 가장 보편적으로 섭취할 수 있는 대표적인 synbiotics 로서 국내외적으로 발효유의 시장규모 또한 꾸준히 증가하 고 있다(2).

발효유는 원유 혹은 탈지유에 유산균이나 효모를 접종하 고 발효시켜 만든 유제품으로 우유 성분 이외에 생성된 발효산물인 lactic acid, peptone, oligossaccharide 등이 함유 되어 우유보다 영양학적으로 우수하다 $(3,4)$. 또한 유산균의 장내 증식에 의한 정장작용(5)과 bacteriocin의 생산에 의한 장내 유해 세균의 생육억제(6), 콜레스테롤 저하(7) 등 건강 
증진 효과가 있는 식품이다. 이처럼 발효유는 건강증진기 능성을 갖는 기호성 식품으로써 메밀(8), 마늘(9), 오가피 (10), 유자(11), 산수유(12), 함초(13), 통보릿가루(14) 등의 기능성 식품들을 첨가하여 기존 발효유보다 기능성을 강화 시키고 항산화활성을 높이는 새로운 형태의 발효유 개발을 위한 연구가 진행되고 있다.

차(Camellia sinensis)는 동백나무과(Theaeceae)에 속하 는 상록활엽수로 열대지방에서 온대지방까지 광범위한 지 역에서 자라고 있다(15). 차는 잎에 열을 가열하여 산화효소 를 불활성화 시킨 비발효차(녹차)와 발효 정도가 $10-55 \%$ 사이인 반발효차(우롱차), 그리고 발효를 $85 \%$ 이상 시킨 발 효차(홍차)로 나눌 수 있다(16). 또한 녹차는 채엽시기에 따라 우전(4월 20일 이전)과 세작(4월 중하순)으로 나눌 수 있으며 세작을 수확 한 후 채엽한 중작(5월 초순), 대작(6 월 초순) 등으로 나누어지며 채엽시기가 빠를수록 좋은 등 급의 차로 여겨진다(17). 녹차를 우려내어 음용할 경우, catechins, caffeine, amino acid, phenolic acid, water soluble vitamin 외에 나머지 성분들은 버려지나 분말화된 가루녹차 를 직접 섭취할 경우, 수용성 성분뿐만 아니라 불용성 성분 인 식이섬유와 지용성 성분인 tocopherol, $\beta$-carotene 등의 유용성분까지 섭취할 수 있다(18). 또한 녹차의 주요 성분인 catechins는 항산화 효능(19,20), 콜레스테롤저하(21), 항암 작용(22), 항균작용(23), 고혈압 및 동맥경화 억제작용 $(24,25)$ 등에 효과가 있다는 연구결과도 있다.

따라서 본 연구에서는 녹차 중 품질이 가장 우수하고 생리활성도가 높은 녹차가루(17)를 첨가하여 제조한 발효 유의 발효특성, 이화학적특성 및 항산화 활성을 조사하였 다.

\section{재료 및 방법}

\section{실험재료}

본 실험에 사용한 녹차는 (주)대한다원쉼터(Boseong, Korea)에서 2016년에 채엽, 가공된 녹차를 구입하여 분쇄기 (MCH-602, Dongyang Magic, Seoul, Korea)로 분말화 한 후 $60 \mathrm{mesh}$ 에 통과시켜 시료로 사용하였다.

\section{사용균주 및 bulk starter 제조}

유산균은 DVS(Direct vat System)형태로 Streptococcus salivarius subsp. thermophilus와 Lactobacillus paracasei, Lactobacillus delbrueckii subsp. bulgaricus 가 혼합된 상업용 유산균 starter(Plain morning, Cellbiotech Co., Seoul, Korea) 를 사용하였다. Bulk starter 제조는 $95^{\circ} \mathrm{C}$ 에서 15 분간 살균하 여 $40^{\circ} \mathrm{C}$ 로 방냉한 우유에 상업용 유산균 starter를 $0.3 \%$ $(\mathrm{w} / \mathrm{w})$ 접종하여 $40^{\circ} \mathrm{C}$ 에서 8 시간 동안 발효한 후 $4{ }^{\circ} \mathrm{C}$ 에서 냉장 보관하며 실험에 사용하였다.

\section{녹차 발효유의 제조}

녹차가루를 첨가한 발효유의 제조는 Table 1 과 같이 배합 하여 사용하였다. 시유(Seoul Milk Co., Seoul, Korea)를 기 질로 하여 탈지분유분말(Seoul Milk Co.), 올리고당(CJ Cheiljedang Co., Seoul, Korea)과 0, 0.5, 1, 2 및 3\% 농도의 녹차가루를 첨가하여 균질화하고 $95^{\circ} \mathrm{C}$ 에서 15 분간 살균하 였다. 살균 후 $40^{\circ} \mathrm{C}$ 로 방냉한 다음 $3 \%(\mathrm{w} / \mathrm{w})$ bulk starter를 접종하여 $40^{\circ} \mathrm{C}$ 에서 12 시간 발효한 후 $4^{\circ} \mathrm{C}$ 에서 1 일간 보관하 며 안정화 시킨 후 각종 분석 실험에 이용하였다.

Table 1. Mixing ratio of yogurt with different ratio of green tea powder

\begin{tabular}{cccccc}
\hline & \multicolumn{5}{c}{ Green tea powder content $(\%, \mathrm{w} / \mathrm{w})$} \\
\cline { 2 - 6 } Ingredient $(\mathrm{g})$ & 0 & 0.5 & 1 & 2 & 3 \\
\hline Milk & 360 & 385 & 356 & 352 & 348 \\
Skim milk powder & 16 & 16 & 16 & 16 & 16 \\
Sugar & 12 & 12 & 12 & 12 & 12 \\
Green tea powder & 0 & 2 & 4 & 8 & 12 \\
Bulk starter ${ }^{1)}$ & 12 & 12 & 12 & 12 & 12 \\
Total & 400 & 400 & 400 & 400 & 400 \\
\hline
\end{tabular}

${ }^{1)}$ It is mixture of Streptococcus salivarius subsp. thermophilus, Lactobacillus paracasei and Lactobacillus delbrueckii subsp. bulgaricus.

\section{$\mathrm{pH}$ 및 적정산도 측정}

발효유의 $\mathrm{pH}$ 는 $\mathrm{pH}$ meter(Mettler Toledo Co., MP225K, Seoul, Korea)를 사용하여 측정하였고, 적정산도는 $\mathrm{AOAC}(26)$ 에 따라 적절히 희석한 시료 $10 \mathrm{~mL}$ 를 $0.1 \mathrm{~N}$ $\mathrm{NaOH}$ 로 $\mathrm{pH}$ 8.3이 될 때까지 적정하여 아래 식에 따라 젖산 (lactic acid)의 산도지수 0.009 를 대입한 후 백분율(\%)로 환산하여 나타내었다.

$$
\text { 적정산도 }(\%)=\frac{\mathrm{V} \times \mathrm{F} \times 0.009 \times 100 \times \mathrm{D}}{\mathrm{S}}
$$

$$
\begin{aligned}
& \mathrm{V}: 0.1 \mathrm{~N} \mathrm{NaOH} \text { 용액의 적정치 소비량 }(\mathrm{mL}) \\
& \mathrm{F}: 0.1 \mathrm{~N} \mathrm{NaOH} \text { 용액의 역가 } \\
& \mathrm{D}: \text { 희석배수 } \\
& \mathrm{S}: \text { 시료의 채취량 }(\mathrm{mL})
\end{aligned}
$$

\section{유산균 수 및 당도 측정}

발효유의 유산균 수 측정은 시료액 $1 \mathrm{~mL}$ 에 멸균수 9 $\mathrm{mL}$ 를 혼합하여 10 배 희석법으로 희석한 후, MRS agar(Difco, Ditroit, MI, USA)에 접종하여 $40^{\circ} \mathrm{C}$ 에서 48 시간 배양한 후 형성된 colony를 계수하여 $\log \mathrm{CFU} / \mathrm{mL}$ 로 환산 하여 표시하였고(27) 당도는 굴절당도계(ATAGO, Co., $\mathrm{N}-1 \mathrm{a}$, Kyoto, Japan)를 이용하여 측정하였다.

색도 측정

색도는 $4^{\circ} \mathrm{C}$ 에서 1 일간 저장한 시료 $10 \mathrm{~g}$ 을 투명한 petri 
$\operatorname{dish}(55 \times 12 \mathrm{~mm})$ 에 담아 표준 백색판 $(\mathrm{L}=97.78, \mathrm{a}=-0.39$, $\mathrm{b}=2.05$ )으로 보정된 색차계(Konica Minolta CM-3600A, Osaka, Japan)를 사용하여 L(lightness), a(redness), $\mathrm{b}$ (yellowness)를 측정하였다. 각 실험은 10 회 반복 수행하 였다.

\section{총 페놀성 화합물 함량 측정}

총 페놀성 화합물 함량 측정은 Folin-Denis법(28)에 따라 비색 정량하였다. 즉, $13,000 \mathrm{rpm}$ 에서 15 분간 원심분리 한 상등액 $2 \mathrm{~mL}$ 에 $1 \mathrm{~N}$ Folin-ciocalteu's reagent $2 \mathrm{~mL}$ 를 가하여 3 분 동안 실온에 방치한 후 $10 \% \mathrm{NaCO}_{3} 2 \mathrm{~mL}$ 를 첨가하여 1 시간 동안 암실에서 반응시킨 다음, 분광광도계(UV-1601, Shimazdu Co., Kyoto, Japan)로 $700 \mathrm{~nm}$ 에서 측정하여 나온 값을 tannic acid 표준곡선에 대입하여 총 페놀성 화합물 함량으로 환산하였다.

\section{DPPH radical 소거능 측정}

1,1-Diphenyl-2-picrylhydrazyl(DPPH) radical 소거능은 free radical인 DPPH 시약이 시료 내의 항산화 물질과 반응 하여 보라색에서 노란색으로 탈색되는 원리를 이용하는 것으로 DPPH radical 소거능은 Blois의 방법(29)을 일부 수 정하여 측정하였다. 시료 $0.3 \mathrm{~mL}$ 에 methanol $10 \mathrm{~mL}$ 를 가하 여 상온에서 5 분간 교반한 후 $3,000 \mathrm{rpm}$ 에서 10 분간 원심분 리하여 얻어진 상등액을 시료용액으로 사용하였다. 96 well ELISA plate에 시료용액 $50 \mu \mathrm{L}$ 와 $0.1 \mathrm{mM}$ DPPH solution(4 $\mathrm{mg} \mathrm{DPPH} / 100 \mathrm{~mL} \mathrm{50 \%} \mathrm{methanol)} 150 \mu \mathrm{L}$ 를 혼합하여 실온 에서 빛이 없는 조건으로 10 분간 반응시킨 후, multi label counter(Victor3, Perkin Elmer, Waltham, MA, USA)로 517 $\mathrm{nm}$ 에서 흡광도를 측정하였다. 이때 대조구로는 ascorbic $\operatorname{acid}(100 \mathrm{ppm})$ 를 사용하여 동일한 조건으로 측정하였으며 $\mathrm{DPPH}$ radical 소거능은 시료 첨가구와 무처리 구의 흡광도 차이를 비교하여 백분율 $(\%)$ 로 나타내었다.

$\mathrm{DPPH}$ radical scavenging activity(\%)=(1- $\left.\frac{\text { 시료첨가구의 흡광도 }}{\text { 무 처리구의 흡광도 }}\right) \times 100$

\section{FRAP 활성 측정}

Ferric ion reducing antioxidant power(FRAP) 활성은 $\mathrm{Fe}$ (III)-2,4,6-tripyridyls-triazine(TPTZ)가 항산화물질에 의해 $\mathrm{Fe}(\mathrm{II}) \mathrm{TPTZ}$ 로 환원되는 원리를 이용하여 분광법으로 측 정하는 방법으로(30) Shahrokh의 방법(31)을 일부 수정하여 측정하였다. 시료 $0.3 \mathrm{~mL}$ 에 methanol $10 \mathrm{~mL}$ 를 가하여 상온 에서 5 분간 교반한 후 $3,000 \mathrm{rpm}$ 에서 10 분간 원심분리하여 얻어진 상등액을 시료용액으로 사용하였다. 96 well ELISA plate에 시료용액 $25 \mu \mathrm{L}$ 에 $300 \mathrm{mM}$ acetate buffer(pH 3.6), $10 \mathrm{mM}$ TPTZ와 $20 \mathrm{mM}$ ferric chloride를 10:1:1 비율로 제조 한 cocktail solution $175 \mu \mathrm{L}$ 를 혼합하여 실온에서 빛이 없는
조건으로 30분간 반응시킨 후, multi label counter(Victor3, Perkin Elmer)로 $590 \mathrm{~nm}$ 에서 흡광도를 측정하였다. 시료의 FRAP 환원능은 trolox 검량선의 회귀식을 이용하여 trolox equivalent $\mathrm{mM}(\mathrm{TE} \mathrm{mM})$ 로 나타내었다.

\section{저장성 조사}

발효유는 발효가 완료된 후 일정기간동안 저온 유통되어 소비되므로 저장기간 중의 품질변화를 확인하기 위하여 발효 완료된 발효유를 $4{ }^{\circ} \mathrm{C}$ 에서 보관하면서 5 일 간격으로 30 일 동안 $\mathrm{pH}$, 적정산도, 유산균 수를 측정하여 비교하였 다.

\section{통계처리}

모든 실험 결과는 3회 반복 실시하여 실험 결과를 평균 표준편차로 나타내었고 실험군 간의 유의성을 검정하기 위하여 SAS 통계처리(Statstical Analysis System, SAS Insititute Inc., Cary, NC, USA)를 이용한 분산분석(ANOVA) 과 Duncan의 다중범위검증(Duncan's multiple range test, $\mathrm{p}<0.05)$ 으로 유의성을 검증하였다(32).

\section{결과 및 고찰}

\section{$\mathrm{pH}$ 및 적정산도}

녹차가루를 첨가한 발효유의 발효시간에 따른 $\mathrm{pH}$ 와 적 정산도의 변화는 Fig 1 과 같다. 발효가 시작되기 전 $\mathrm{pH}$ 는 6.43-6.46이였으며 발효시간이 경과함에 따라 모든 시료군 의 $\mathrm{pH}$ 가 유의적으로 감소하였다 $(\mathrm{p}<0.05)$. 발효 완료 후 모 든 실험구의 $\mathrm{pH}$ 가 4.35-4.51로 발효유의 적정 $\mathrm{pH}$ 범위인 3.27-4.53 내에 도달하였다(33). 발효 6시간 경과 시 대조군 보다 첨가군에서 더 낮은 $\mathrm{pH}$ 를 나타냈는데, 이는 녹차 속에 함유되어있는 생리활성물질이 유산균의 생장 향상에 영향 을 준 것으로 사료된다. 하지만 발효가 완료된 12 시간 후 대조군의 $\mathrm{pH}$ 는 4.35 로 가장 낮았고 녹차가루의 첨가량이 증가할수록 $\mathrm{pH}$ 가 높아지는 경향이 나타났으며, Wee와 $\operatorname{Park}(34)$ 의 연구에 의하면 천연보존제인 차엽카테킨이 미 생물에 대하여 생육저해효과가 있음을 보고하였으며, 본 연구에서도 유산균이 차엽카테킨에 의해 생육이 저해되었 다고 보여진다.

녹차가루를 첨가한 발효유의 발효시간에 따른 산도는 발효 전 대조군이 0.14 로 가장 낮았으며 $0.5 \%$ 첨가군은 $0.19,1 \%$ 는 $0.2,2 \%$ 는 $0.22,3 \%$ 는 0.27 로 녹차가루의 첨가량 이 증가할수록 유의적으로 증가하였다 $(\mathrm{p}<0.05)$. 이는 녹차 속에 함유되어있는 citric acid, malic acid등과 같은 유기산 의 영향으로 생각되며(35) 오가피분말(10), 산수유 추출물 (12)을 첨가한 발표유의 품질특성 연구에서도 이와 같은 경향을 나타내었다. 또한 발효가 진행됨에 따라 모든 실험 
군에서의 산도가 점차적으로 증가하여 최종 산도는 $0.80-1.10 \%$ 로 발효유의 적정산도 범위인 0.7-1.2\%에 포함 되었다(36). Kim(37)의 연구에 의하면 발효가 진행됨에 따 라 유산균의 증식 및 대사 활동으로 인해 젖산이 생성되어 총 유기산의 양이 증가한다고 보고하였으며, 본 연구에서 도 앞선 연구와 비슷한 결과를 나타내었다.
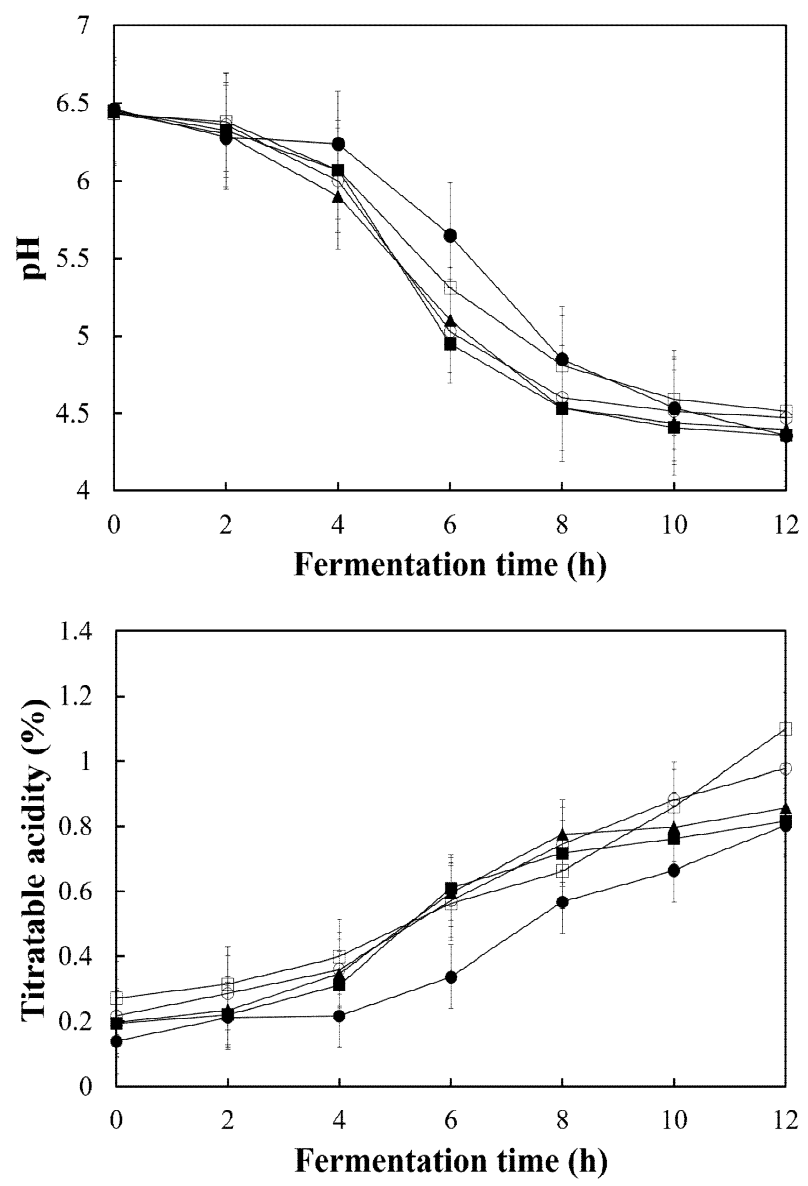

Fig. 1. Changes in the pH and titratable acidity (TA) during lactic acid fermentation of fermented milk with different green tea powder.

, fermented milk without green tea powder; $\mathbf{\square}$, fermented milk with $0.5 \%$ green tea powder; $\boldsymbol{\Delta}$, fermented milk with $1 \%$ green tea powder; $\bigcirc$, fermented milk with $2 \%$ green tea powder; $\square$, fermented milk with $3 \%$ green tea powder.

All the data were expressed as mean $\pm \mathrm{SD}(\mathrm{n}=3)$.

\section{유산균 수 및 당도 측정}

녹차가루를 첨가한 발효유의 발효 중 유산균 수와 당도 의 변화는 Fig 2 와 같다. 발효가 진행됨에 따라 모든 실험군 에서 유산균 수가 서서히 증가하였으며 $0.5 \%$ 첨가군의 경 우 대조군과 유의적인 차이가 없었으나 $1 \%$ 이상의 녹차가 루를 첨가할 경우 첨가량이 증가할수록 유산균 수는 감소하 는 경향을 나타내었다. Bang과 Park(38)의 연구에 의하면 녹차 물추출물을 첨가한 요구르트에서 녹차 물추출물에 의해 유산균의 생육이 저해된다고 보고하였고, Park 등(39) 은 녹차를 첨가한 김치가 무첨가구에 비해 적숙기가 길어졌 다고 보고하였는데 이는 녹차에 의해 김치유산균의 생육이
저해된다는 것을 의미하는 것으로 본 연구와 일치하는 결과 이며, 녹차가루에 함유된 카테킨류가 유산균의 생육을 저 해시켰다고 판단된다(34). 또한 오가피분말(10), 통보릿가 루(14)를 첨가한 발효유에서 부재료의 첨가량이 증가함에 따라 유산균 수가 감소되었다고 보고하였고 본 연구에서도 비슷한 경향을 나타내었다. 한편, 발효 4시간 후 모든 실험 군에서 유산균 수가 8.57-8.89 $\log \mathrm{CFU} / \mathrm{mL}$ 에 도달하여 우리 나라의 축산물 가공기준 및 성분규격상 발효유의 총 유산균 수 기준인 $10^{8} \mathrm{CFU} / \mathrm{mL}$ 이상의 성분규격에 충족하였다.

발효 전 모든 실험군에서 당도는 $18.8-19.0^{\circ} \mathrm{Brix}$ 였으나 발효가 진행됨에 따라 감소하여 발효 12시간 후에는 12-13 ${ }^{\circ} \mathrm{Brix}$ 를 나타내었다. 오가피분말(10), 스피루리나(40)를 첨 가한 발효유에서도 발효가 진행됨에 따라 발효유의 당도가 유의적으로 감소하였다고 보고하였으며, 본 연구에서도 발 효가 진행됨에 따라 당도가 감소한 것을 보아 발효기간 동안 유산균에 의해 발효유 속 당이 분해되어 유산 및 초산 과 같은 발효산물들이 생성되었기 때문으로 보여진다.
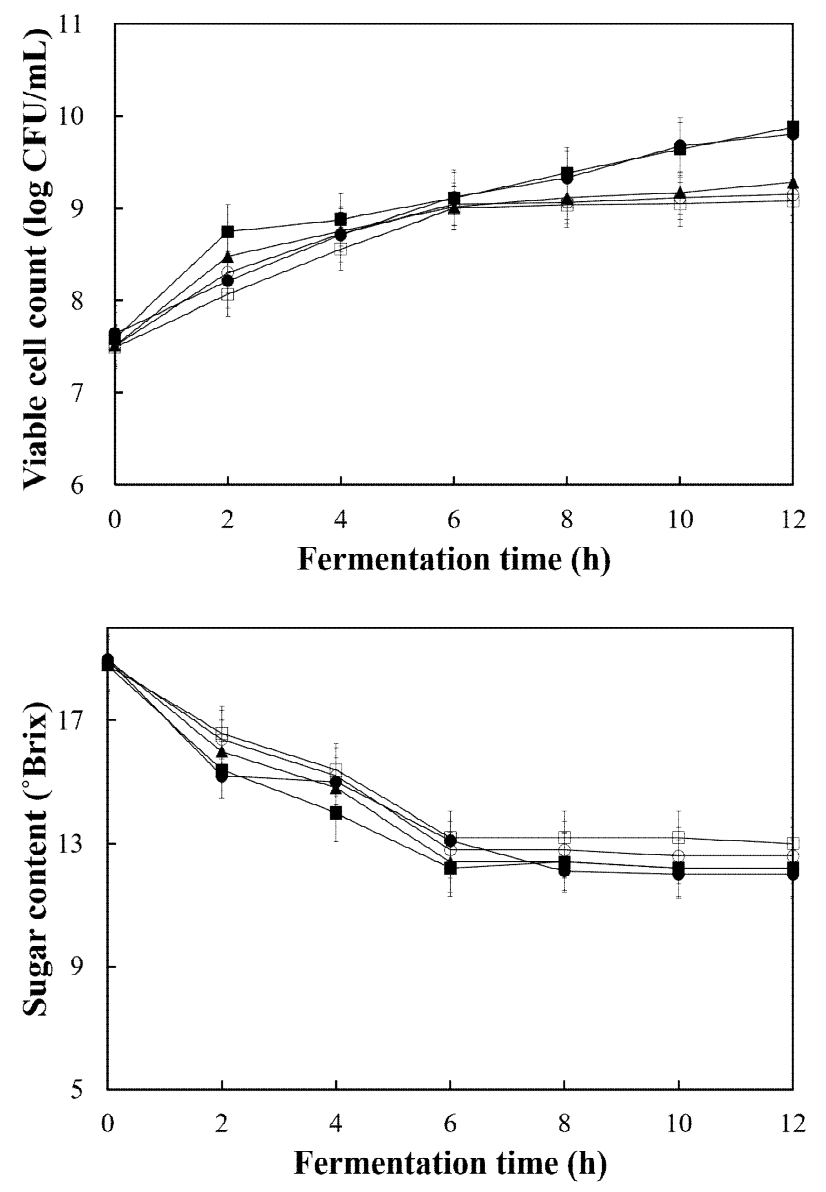

Fig. 2. Changes in the viable cell count and sugar content during lactic acid fermentation of fermented milk with different green tea powder.

$\boldsymbol{0}$, fermented milk without green tea powder; $\mathbf{\square}$, fermented milk with $0.5 \%$ green tea powder; $\boldsymbol{\Delta}$, fermented milk with $1 \%$ green tea powder; $\bigcirc$, fermented milk with $2 \%$ green tea powder; $\square$, fermented milk with $3 \%$ green tea powder. All the data were expressed as mean $\pm \mathrm{SD}(\mathrm{n}=3)$. 


\section{색 도}

녹차가루의 첨가량을 달리한 발효유의 발효 전과 발효 후의 $\mathrm{L}, \mathrm{a}, \mathrm{b}$ 값은 Table 2 와 같다. 녹차가루를 첨가한 실험군 의 명도는 발효 전보다 발효 후에 유의적으로 낮아졌으며, 발효 후에 대조군과 녹차가루 $0.5,1,2,3 \%$ 첨가군의 명도는 각각 $71.91,66.25,64.04,62.23,60.58$ 로 녹차가루의 농도가 증가할수록 낮아지는 경향을 보였다. 또한 적색도 역시 대 조군이 -2.06 으로 가장 높게 나타났으며 녹차가루의 첨가량 이 증가할수록 감소하는 경향을 보여 $3 \%$ 첨가군에서는 -3.40 으로 가장 낮은 값을 나타냈다. 황색도는 녹차가루의 첨가량에 따라 유의적으로 증가하여 대조군은 4.37 로 가장 낮은 값을 나타냈으며 $3 \%$ 첨가군에서는 12.54 로 가장 높게 나타났다. $1,3,5 \%$ 의 녹차가루를 첨가하여 식빵을 제조한 Park과 Lee(41)의 연구결과에서도 녹차가루 첨가량이 증가 함에 따라 명도와 적색도는 낮아졌으며 황색도는 증가한다 고 보고하였다. 이는 녹차가루 자체의 색도 때문이라고 판 단되며, 본 연구에서도 유사한 경향을 나타내었다.

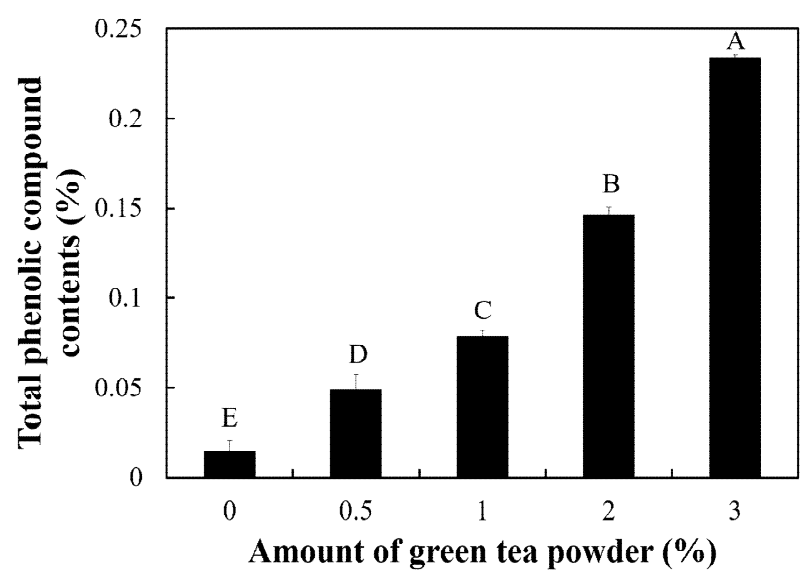

Fig. 3. Total phenolic compound contents of the fermented milk with different green tea powder.

All the data were expressed as mean $\pm \mathrm{SD}(\mathrm{n}=3)$.

Different letters above the bars indicate significantly different $(\mathrm{p}<0.05)$.

Table 2. Hunter's color values of the fermented milk with different amount of green tea powder

\begin{tabular}{|c|c|c|c|c|c|c|}
\hline \multirow{2}{*}{ Color value ${ }^{1)}$} & \multirow{2}{*}{ fermentation } & \multicolumn{5}{|c|}{ Amount of green tea powder content $(\%)$} \\
\hline & & 0 & 0.5 & 1 & 2 & 3 \\
\hline \multirow{3}{*}{$\mathrm{L}$} & Before & $69.59 \pm 0.03^{2 / 23)}$ & $68.11 \pm 0.02^{\mathrm{b}}$ & $67.07 \pm 0.02^{c}$ & $65.88 \pm 0.05^{\mathrm{d}}$ & $64.69 \pm 0.20^{\mathrm{e}}$ \\
\hline & After & $71.91 \pm 0.02^{\mathrm{a}}$ & $66.25 \pm 0.04^{\mathrm{b}}$ & $64.04 \pm 0.03^{\mathrm{c}}$ & $62.23 \pm 0.03^{\mathrm{d}}$ & $60.58 \pm 0.05^{\mathrm{e}}$ \\
\hline & Before & $-2.01 \pm 0.00^{\mathrm{a}}$ & $-3.08 \pm 0.01^{b}$ & $-3.85 \pm 0.01^{\mathrm{c}}$ & $-4.82 \pm 0.01^{\mathrm{d}}$ & $-5.36 \pm 0.01^{\mathrm{e}}$ \\
\hline \multirow[t]{2}{*}{ a } & After & $-2.06 \pm 0.01^{\mathrm{a}}$ & $-2.25 \pm 0.00^{\mathrm{b}}$ & $-2.63 \pm 0.00^{c}$ & $-3.04 \pm 0.01^{\mathrm{d}}$ & $-3.40 \pm 0.01^{\mathrm{e}}$ \\
\hline & Before & $2.19 \pm 0.01^{\mathrm{e}}$ & $5.96 \pm 0.01^{\mathrm{d}}$ & $8.87 \pm 0.00^{\mathrm{c}}$ & $11.08 \pm 0.02^{\mathrm{b}}$ & $12.47 \pm 0.08^{\mathrm{a}}$ \\
\hline $\mathrm{b}$ & After & $4.37 \pm 0.00^{\mathrm{e}}$ & $8.08 \pm 0.00^{\mathrm{d}}$ & $9.83 \pm 0.01^{\mathrm{c}}$ & $11.29 \pm 0.01^{\mathrm{b}}$ & $12.54 \pm 0.01^{\mathrm{a}}$ \\
\hline
\end{tabular}

${ }^{1)} \mathrm{L}$, lightness; a, redness; $b$, yellowness.

${ }^{2)}$ The values were expressed as mean \pm SD $(n=10)$.

${ }^{3)}$ Different letters within the same row indicate significant difference $(\mathrm{p}<0.05)$.

\section{총 페놀성 화합물 함량 측정}

녹차의 주요 폴리페놀 화합물인 catechins 외에도 flavonoid와 tocopherol 및 tannin 등을 함유하고 있으며(42), 이러한 폴리페놀 물질들은 뛰어난 항산화 작용으로 체내 활성산소 제거 효과에 탁월하다. 녹차가루의 첨가량을 달 리한 발효유의 총 페놀성 화합물 함량은 Fig. 3에 나타내었 다. 녹차가루를 첨가하지 않은 대조군에서 $0.014 \%$ 로 가장 낮았으며, 녹차가루의 첨가량이 증가할수록 총 페놀성 화 합물 함량이 증가하여 $0.5 \%$ 첨가군에서 $0.048 \%, 1 \%$ 첨가군 에서 $0.078 \%, 2 \%$ 첨가군에서 $0.146 \%$ 가 나타났고 $3 \%$ 첨가 군에서 약 $0.233 \%$ 로 가장 많은 페놀 함량이 나타났다. Cho 등(43)은 녹차 속 catechins 와 flavonoid 및 그 외 다양한 페놀성 화합물이 함유되어있으며 녹차 첨가량이 증가 할수 록 막걸리의 총 페놀성 화합물 함량이 증가되었다고 보고하 였고 본 연구에서도 비슷한 경향을 나타내었다.

\section{항산화능 측정}

녹차가루의 첨가량을 달리한 발효유의 기능성을 평가하 기 위하여 DPPH radical 소거능, FRAP 활성을 측정하였으 며, 그 결과들은 Fig. 4에 나타내었다. DPPH radical 소거능 분석 결과, 발효 전보다 발효 후에 모든 실험군에서 DPPH radical 소거능 값이 유의적으로 증가한 것을 확인하였고, 이러한 결과는 유산균의 젖산 발효에 의해 생성된 대사물질 과 젖산 등에 의한 작용으로 보여지며 아로니아(2)를 첨가 한 발효유의 결과와 일치하였다. 또한 발효 후 DPPH radical 소거능 분석 결과, 대조군이 $13.5 \%$ 로 가장 낮은 값을 나타 내었고, $0.5 \%$ 첨가군은 $63.53 \%, 1 \%$ 첨가군은 $68.34 \%, 2 \%$ 첨가군은 $77.13 \% 3 \%$ 첨가군의 radical 소거능은 $80.13 \%$ 로 가장 높게 나타났으며 녹차가루의 첨가량이 증가할수록 값이 높은 값으로 나타났다. FRAP 활성 분석 결과에서도 녹차가루 첨가군에서 대조군(0.04 $\mu \mathrm{M} \mathrm{TE})$ 보다 높은 0.334-1.490 $\mu \mathrm{M}$ TE의 FRAP 활성을 나타내었으며 녹차가 
루의 첨가량이 증가할수록 값이 증가하는 것을 확인하였 다. $\operatorname{Kim}(42)$ 은 녹차 속 폴리페놀 화합물인 catechins에 의해 높은 항산화 활성을 나타낸다고 보고하였고, Lee 등(44)의 연구에서는 단순회귀분석을 통해 $\mathrm{EC}, \mathrm{ECG}$ 및 $\mathrm{EGCG}$ 함량 과 항산화 활성과 상관관계가 있으며, 녹차의 항산화 활성 은 카테킨류에 의해 상당 부분 결정된다고 보고하였다. 본 연구에서도 앞선 연구들과 비슷한 결과를 나타내었으며 catechins 외에도 녹차 속에 함유되어 있는 다량의 flavonol 와 vitamin(43)등의 다양한 항산화 활성 물질들을 함유하고 있어 높은 항산화력을 나타내므로 녹차가루 첨가가 발효유 의 항산화 활성을 증가시킨 것으로 판단된다.
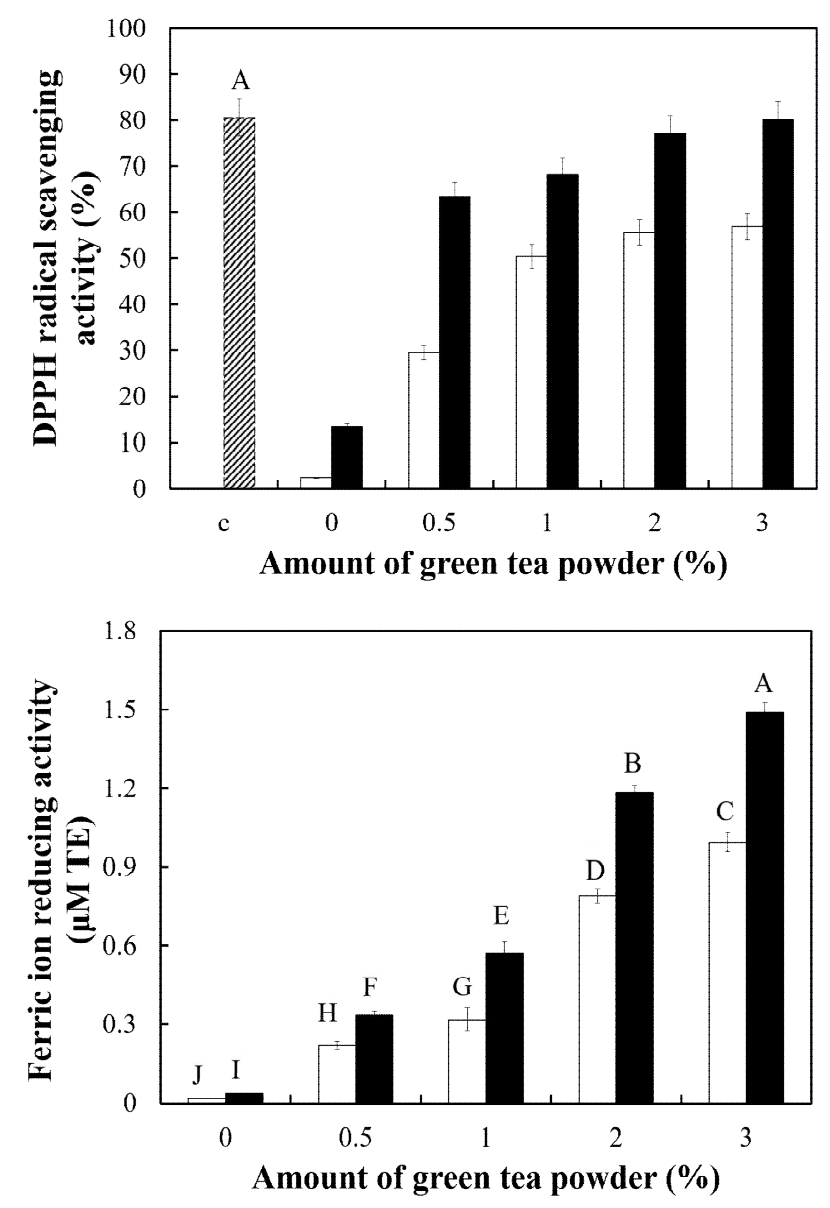

Fig. 4. DPPH free radical scavenging activity and ferric ion reducing antioxidant power of the fermented milk with different green tea powder.

$\bigotimes$, Control(ascorbic acid $100 \mathrm{ppm}$ ); $\square$, fermented milk before the fermentation; fermented milk after the fermentation during $12 \mathrm{~h}$.

All the data were expressed as mean $\pm S D(n=3)$.

Different letters above the bars indicate significantly different $(\mathrm{p}<0.05)$

\section{발효유의 저장성}

발효가 완료된 발효유는 오랜 기간 저온에서 유통, 보관 되므로 저장 기간 중의 품질변화를 확인하기 위하여 발효가 완료된 후 $4^{\circ} \mathrm{C}$ 에서 보관하면서 30 일간 5 일 간격으로 $\mathrm{pH}$,
적정산도, 유산균 수 및 색도를 조사하였다. 먼저 $\mathrm{pH}$ 와 산도 의 결과는 Fig. 5 에 나타내었으며, 저장기간 동안 모든 실험 군의 $\mathrm{pH}$ 는 서서히 감소하였고, 적정산도는 서서히 증가하 였으며 저장 기간 동안의 $\mathrm{pH}$ 와 산도는 발효유의 적정 범위
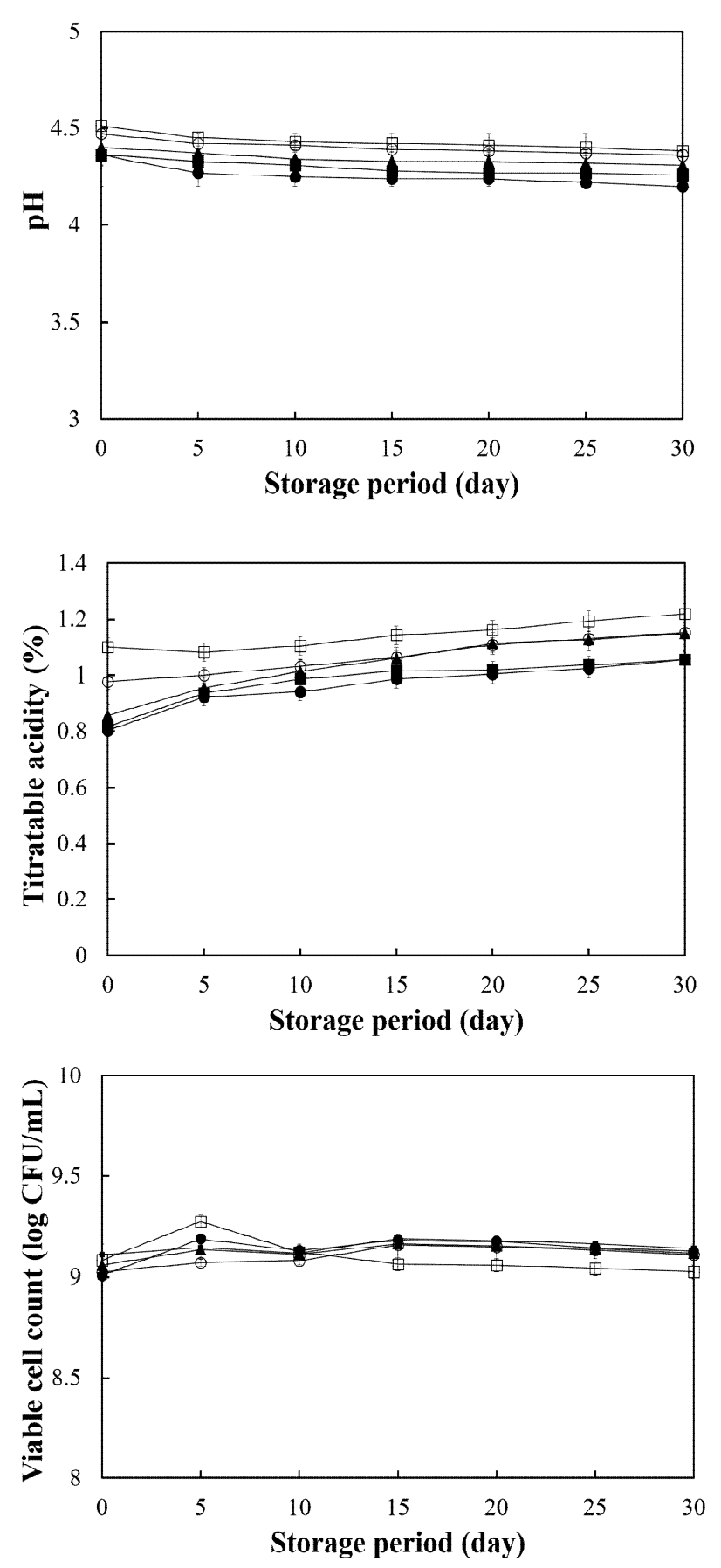

Fig. 5. Changes in the pH, titratable acidity (TA) and viable cell count during fermentation of fermented milk with different green tea powder.

, fermented milk without green tea powder; $\mathbf{\square}$, fermented milk with $0.5 \%$ green tea powder; $\boldsymbol{\Delta}$, fermented milk with $1 \%$ green tea powder; $\bigcirc$, fermented milk with $2 \%$ green tea powder, $\square$, fermented milk with $3 \%$ green tea powder. All the data were expressed as mean $\pm \mathrm{SD}(\mathrm{n}=3)$.

Different letters above the bars indicate significantly different $(\mathrm{p}<0.05)$. 
내에 유지되었다(33,36). 아로니아(2)를 첨가한 발효유의 저장 중 품질변화는 유산균의 후산 발효로 인한 결과로 산의 양이 증가하여 산도가 증가했다고 보고하였고 본 연구 에서의 결과와 유사하였다. 유산균 수는 모든 실험군에서 서서히 증가하다가 15 일이 지난 후부터 감소하는 경향이 나타났다. 오가피분말(10), 스피루리나(40)를 첨가한 발효 유에서도 일정 기간이 지나면 유산균 수가 서서히 감소하는 경향을 나타냈으며 본 연구에서도 앞선 연구들과 비슷한 결과를 나타내었다. 또한 축산물 가공기준 및 성분규격에 의한 유산균 수 기준인 $10^{8} \mathrm{CFU} / \mathrm{mL}$ 이상의 값에 충족하여 녹차가루 첨가가 발효유 내 유산균 생육에 부정적인 영향을 주지 않기 때문에 저장성에 문제가 없을 것으로 사료된다. 저장 중 색도 $\mathrm{L}, \mathrm{a}, \mathrm{b}$ 값은 Table 3 같다. 저장 기간 동안 명도는 발효 완료 직후의 발효유와 유사하게 녹차의 첨가량 이 증가할수록 감소하였으나 적색도는 증가하였는데 이는 녹차 속 색소가 페오피틴으로 변하게 되어 붉은 색이 증가 했을 것으로 판단되며, 이는 Hong 등(45)의 가루녹차를 첨 가한 설기떡의 실험에서도 저장 중 적색도는 증가한다고 보고하여 본 연구와 같은 경향을 나타내었다. 반면 황색도 는 발효 완료 직후보다 증가하였으나 유의적인 차이는 없었 다. 이상의 결과를 종합해 보면 녹차가루 첨가가 발효유의 저장 기간 중 $\mathrm{pH}$, 산도, 생균수 및 색도의 변화에 영향을 미치지 않는 것으로 판단된다.

\section{요 약}

본 연구에서는 녹차가루의 첨가량을 $0.5,1,2,3 \%$ 를 첨가 한 발효유를 제조하고 이에 따른 품질특성, 항산화 활성 및 저장성을 평가하였다. 녹차가루를 첨가한 발효유에서 발효가 진행될수록 $\mathrm{pH}$ 는 낮아졌으나 대조군에 비해 첨가 군에서 높은 값을 나타내었고 적정산도 역시 발효가 진행될 수록 증가하였으나 녹차가루의 첨가량이 증가할수록 적정 산도는 높아지는 경향을 나타내었다. 시간이 지날수록 유 산균 수는 증가하였으나 대조군에 비해 적었으며 당도는 낮아졌다. 색도의 경우 녹차가루의 첨가량이 증가할수록 $\mathrm{L}$ 값과 $\mathrm{a}$ 값은 낮아졌고 $\mathrm{b}$ 값은 증가하였다. DPPH radical 소거능과 FRAP에 대한 항산화활성은 녹차가루의 첨가량 이 증가할수록 높아지는 경향을 보였다. 발효가 완료된 발 효유를 $4^{\circ} \mathrm{C}$ 에서 30 일간 저장한 결과, $\mathrm{pH}$ 와 적정산도, 유산 균 수 모두 적정 발효유의 범위 내에 속하였으며 색도는 녹차의 갈변에 의한 적색도 값이 증가하였으나 큰 변화는 없었다. 이러한 결과로 보아 발효유 제조 시 녹차가루의 첨가는 발효유의 발효 및 품질특성에 부정적인 영향을 미치 지 않고 건강기능성을 향상시켜 새로운 기능성 발효유로써 의 개발 가능성을 확인하였다.

Table 3. Hunter's color values of the yogurt with different amount of green tea powder during storage period at $4^{\circ} \mathrm{C}$

\begin{tabular}{|c|c|c|c|c|c|c|c|c|}
\hline \multirow{2}{*}{$\begin{array}{l}\text { Green tea powder } \\
\text { content }(\%)\end{array}$} & \multirow{2}{*}{ Color value ${ }^{1)}$} & \multicolumn{7}{|c|}{ Storage period (day) } \\
\hline & & 0 & 5 & 10 & 15 & 20 & 25 & 30 \\
\hline \multirow{3}{*}{0} & $\mathrm{~L}$ & $71.91 \pm 0.02^{2(\mathrm{G} 3)}$ & $80.89 \pm 0.01^{\mathrm{B}}$ & $81.91 \pm 0.02^{\mathrm{A}}$ & $79.91 \pm 0.01^{\mathrm{C}}$ & $77.90 \pm 0.00^{\mathrm{E}}$ & $75.92 \pm 0.03^{\mathrm{F}}$ & $77.91 \pm 0.05^{\mathrm{D}}$ \\
\hline & $\mathrm{a}$ & $-2.06 \pm 0.02^{\mathrm{G}}$ & $-1.5 \pm 0.01^{F}$ & $-0.84 \pm 0.01^{\mathrm{E}}$ & $-0.19 \pm 0.02^{\mathrm{D}}$ & $-0.2 \pm 0.00^{\mathrm{C}}$ & $-0.05 \pm 0.02^{\mathrm{B}}$ & $0.02 \pm 0.02^{\mathrm{A}}$ \\
\hline & $\mathrm{b}$ & $4.37 \pm 0.02^{\mathrm{G}}$ & $7.04 \pm 0.01^{\mathrm{F}}$ & $7.11 \pm 0.01^{\mathrm{E}}$ & $7.57 \pm 0.02^{\mathrm{D}}$ & $8.31 \pm 0.00^{\mathrm{C}}$ & $8.45 \pm 0.02^{\mathrm{B}}$ & $8.81 \pm 0.00^{\mathrm{A}}$ \\
\hline \multirow{3}{*}{0.5} & $\mathrm{~L}$ & $66.25 \pm 0.04^{\mathrm{A}}$ & $63.74 \pm 0.01^{\mathrm{B}}$ & $63.24 \pm 0.02^{\mathrm{C}}$ & $63.13 \pm 0.01^{\mathrm{D}}$ & $62.78 \pm 0.04^{\mathrm{E}}$ & $62.33 \pm 0.04^{\mathrm{F}}$ & $62.25 \pm 0.03^{\mathrm{G}}$ \\
\hline & $\mathrm{a}$ & $-2.25 \pm 0.02^{\mathrm{G}}$ & $-0.86 \pm 0.00^{\mathrm{F}}$ & $0.02 \pm 0.04^{\mathrm{E}}$ & $0.42 \pm 0.00^{\mathrm{D}}$ & $0.88 \pm 0.02^{\mathrm{C}}$ & $1.16 \pm 0.01^{B}$ & $1.25 \pm 0.00^{\mathrm{A}}$ \\
\hline & $\mathrm{b}$ & $8.80 \pm 0.02^{\mathrm{G}}$ & $11.79 \pm 0.02^{\mathrm{F}}$ & $12.03 \pm 0.01^{\mathrm{E}}$ & $13.24 \pm 0.00^{\mathrm{D}}$ & $14.01 \pm 0.02^{\mathrm{C}}$ & $14.08 \pm 0.00^{\mathrm{B}}$ & $14.58 \pm 0.02^{\mathrm{A}}$ \\
\hline \multirow{3}{*}{1} & $\mathrm{~L}$ & $64.04 \pm 0.03^{\mathrm{B}}$ & $65.76 \pm 0.04^{\mathrm{A}}$ & $64.03 \pm 0.00^{\mathrm{C}}$ & $63.94 \pm 0.01^{\mathrm{D}}$ & $62.53 \pm 0.00^{\mathrm{E}}$ & $61.54 \pm 0.01^{\mathrm{F}}$ & $60.10 \pm 0.01^{\mathrm{G}}$ \\
\hline & $\mathrm{a}$ & $-2.63 \pm 0.02^{\mathrm{G}}$ & $0.6 \pm 0.04^{\mathrm{E}}$ & $0.53 \pm 0.01^{\mathrm{F}}$ & $1.05 \pm 0.03^{D}$ & $1.18 \pm 0.04^{\mathrm{C}}$ & $1.36 \pm 0.00^{\mathrm{B}}$ & $1.53 \pm 0.03^{\mathrm{A}}$ \\
\hline & $\mathrm{b}$ & $9.83 \pm 0.00^{\mathrm{G}}$ & $12.17 \pm 0.01^{\mathrm{F}}$ & $12.99 \pm 0.00^{\mathrm{E}}$ & $13.46 \pm 0.00^{\mathrm{D}}$ & $14.77 \pm 0.03^{\mathrm{C}}$ & $15.0 \pm 0.02^{\mathrm{B}}$ & $15.78 \pm 0.00^{\mathrm{A}}$ \\
\hline \multirow{3}{*}{2} & $\mathrm{~L}$ & $62.23 \pm 0.03^{B}$ & $64.48 \pm 0.04^{\mathrm{A}}$ & $59.22 \pm 0.00^{\mathrm{C}}$ & $57.11 \pm 0.00^{\mathrm{D}}$ & $56.54 \pm 0.02^{\mathrm{E}}$ & $56.53 \pm 0.04^{F}$ & $55.25 \pm 0.03^{\mathrm{G}}$ \\
\hline & a & $-3.04 \pm 0.00^{\mathrm{G}}$ & $0.71 \pm 0.01^{\mathrm{F}}$ & $1.14 \pm 0.05^{\mathrm{E}}$ & $1.26 \pm 0.08^{\mathrm{D}}$ & $1.40 \pm 0.03^{\mathrm{C}}$ & $1.53 \pm 0.02^{\mathrm{B}}$ & $1.69 \pm 0.03^{\mathrm{A}}$ \\
\hline & $\mathrm{b}$ & $11.29 \pm 0.00^{G}$ & $12.88 \pm 0.02^{\mathrm{F}}$ & $13.02 \pm 0.03^{\mathrm{E}}$ & $14.02 \pm 0.00^{\mathrm{D}}$ & $14.95 \pm 0.01^{\mathrm{C}}$ & $16.02 \pm 0.01^{\mathrm{B}}$ & $16.45 \pm 0.00^{\mathrm{A}}$ \\
\hline \multirow{3}{*}{3} & $\mathrm{~L}$ & $60.58 \pm 0.00^{\mathrm{B}}$ & $61.67 \pm 0.02^{\mathrm{A}}$ & $57.80 \pm 0.04^{\mathrm{C}}$ & $56.54 \pm 0.01^{\mathrm{D}}$ & $55.01 \pm 0.01^{\mathrm{E}}$ & $54.56 \pm 0.02^{\mathrm{F}}$ & $53.90 \pm 0.02^{\mathrm{G}}$ \\
\hline & $\mathrm{a}$ & $-3.4 \pm 0.01^{\mathrm{G}}$ & $0.85 \pm 0.01^{\mathrm{F}}$ & $1.26 \pm 0.00^{\mathrm{E}}$ & $1.38 \pm 0.02^{\mathrm{D}}$ & $1.54 \pm 0.05^{\mathrm{C}}$ & $1.73 \pm 0.01^{\mathrm{B}}$ & $1.89 \pm 0.05^{\mathrm{A}}$ \\
\hline & $\mathrm{b}$ & $12.54 \pm 0.04^{\mathrm{G}}$ & $13.03 \pm 0.00^{\mathrm{F}}$ & $13.89 \pm 0.01^{\mathrm{E}}$ & $14.99 \pm 0.03^{\mathrm{D}}$ & $15.24 \pm 0.00^{\mathrm{C}}$ & $16.33 \pm 0.02^{\mathrm{B}}$ & $16.88 \pm 0.04^{\mathrm{A}}$ \\
\hline
\end{tabular}

${ }^{1)} \mathrm{L}$, lightness; a, redness; b, yellowness.

${ }^{2}$ The values were expressed as mean $\pm \mathrm{SD}(\mathrm{n}=10)$.

${ }^{3}$ Different letters within the same row indicate significant difference $(\mathrm{p}<0.05)$. 


\section{감사의 글}

본 연구는 2017년 한국연구재단 과제(2017R1D1A3B03033451) 의 연구비 지원에 의해 수행되었으며 이에 감사드립니다.

\section{References}

1. Xiao J, Zhang Y, Yang Z (2014) Lactic Acid Bacteria in Health and Disease. In: Lactic Acid Bacteria, Springer, Dordrecht, Netherlands, p 303-374

2. Kwon SJ (2016) Effect of addition of aronia juice on the fermentation and physicochemical properties of yogurt. MS Thesis, Kyungpook National University, Korea, $\mathrm{p} 1$

3. Bang BH, Jeong EJ (2007) A study on manufacturing black soybean yogurt. Korean J Food Nutr, 20, 289-294

4. Hong SM, Gu MS, Chung EC, Kang PG, Kim CH (2015) Quality characteristics of yogurt prepared with rice bran Streptococcus thermophilus and Lactobacillus casei. J Milk Sci Biotechnol, 33, 17-25

5. Gilliland SE (1989) Acidophilus milk products: A review of potential benefits to consumers. J Dairy Sci, 72, 2483-2494

6. Kim HK (2002) Probiotic charaterization of lactic acid bacteria used for fermented milk. MS Thesis, Chungnam National University, Korea, p 48-52

7. Anderson JW, Gilliland SE (1999) Effect of fermented milk (yogurt) containing Lactobacillus acidophilus L1 on serum cholesterol in hypercholesterolemic humans. J Am Coll Nutr, 18, 43-50

8. Kang HN, Kim CJ (2009) Lactobacillus bulgaricus fermentation characteristics of yogurt with added buckwheat sprout. J Korean Soc Food Cult, 24, 90-95

9. Cho JR, Kim JH, In MJ (2007) Effect of garlic powder on preparation and quality characteristics of yogurt. $\mathrm{J}$ Korean Soc Appl Biol Chem, 50, 48-52

10. Oh HS, Kang ST (2015) Quality characteristics and antioxidant activity of yogurt added with acanthopanax powder. Korean J Food Sci Technol, 47, 765-771

11. Lee YJ, Kim SI, Han YS (2008) Antioxidant activity and quality characteristics of yogurt added yuza (Citrus junos Sieb ex Tanaka) extract. Korean J Food Nutr, 21, 135-142

12. Kang BS, Kim JI, Moon SW (2012) Quality characteristics of yogurt added with Sansuyu (Corni fructus) extracts. Korean J Culinary Res, 18, 180-190
13. Cho YS, Kim SI, Han YS (2008) Effect of slander glasswort extract yogurt on quality during storage. Korean J Food Cook Sci, 24, 212-221

14. Lee MJ, Kim KS, Kim YK, Park JC, Kim HS, Choi JS, Kim KJ (2013) Quality characteristics and antioxidant activity of yogurt added with whole barley flour. Korean J Food Sci Technol, 45, 721-726

15. Cha WS, Cho MJ, Ding JL, Shin HJ (2008) Nutritional component analysis of green tea tree's root and seed. KSBB J, 23, 387-391

16. Lee HJ (2011) Studies on free and bound aroma compounds in green tea and fermented tea. MS Thesis, Kyunghee University, Korea, $p 1$

17. Park KR, Lee SG, Nam TG, Kim YJ, Kim YR, Kim DO (2009) Comparative analysis of catechins and antioxidant capacity in various grades of organic green teas grown in Boseong, Korea. Korean J Food Sci Technol, 41, 82-86

18. Park JH, Kim YO, Kug YI, Cho DB, Choi HK (2003) Effects of green tea powder on noodle properties. J Korean Soc Food Sci Nutr, 32, 1021-1025

19. Serafini M, Ghiselli A, Ferro-Luzzi A (1996) In vivo antioxidant effect of green and black tea in man. Eur J Clin Nutr, 50, 28-32

20. Seeram NP, Henning SM, Niu Y, Lee R, Scheuller HS, Heber D (2006) Catechin and caffeine content of green tea dietary supplements and correlation with antioxidant capacity. J Agric Food Chem, 54, 1599-1603

21. Bursill CA, Abbey M, Roach PD (2007) A green tea extract lowers plasma cholesterol by inhibiting cholesterol synthesis and upregulating the LDL receptor in the cholesterol-fed rabbit. Atherosclerosis, 193, 86-93

22. Suganuma M, Okabe S, Sueoka N, Sueoka E, Matsuyama S, Imai K, Nakachi K, Fujiki H (1999) Green tea and cancer chemoprevention. Mutat Res-Fundam Mol Mech, mutagen, 428, 339-344

23. Amarowicz R, Pegg RB, Bautista DA (2000) Antibacterial activity of green tea polyphenols against Escherichia coli $\mathrm{K}$ 12. Nahrung, 44, 60-62

24. Kim SB, Lee MJ, Hong J, Li C, Smith TJ, Yang GY, Seril DN, Yang CS (2000) Plasma and tissue levels of tea catechins in rats and mice during chronic consumption of green tea polyphenols. Nutr Cancer, 37, 41-48

25. Nakachi K, Matsuyama S, Miyake S, Suganuma M, Imai K (2000) Preventive effects of drinking green tea on cancer and cardiovascular disease: Epidemiological evidence for multiple targeting prevention. BioFactors, 
$13,49-54$

26. AOAC (2000) Official Method of Analysis of AOAC. $17^{\text {th }}$ ed, International Association of Official Analytical Communities, Gaithersburg, MD, USA, p 1-26

27. KFDA (2010) Korean food \& Drug administration food code. Seoul, Korea, p 3-25

28. Amerine MA, Ough CS (1980) Methods for Analysis of Musts and Wines. John Wiley and Sons Ltd, New York, NY, USA, p 176-180

29. Blois MS (1958) Antioxidant determinations by the use of a stable free radical. Nature, 181, 1199-1200

30. Benzie IFF, Strain JJ (1996) The ferric reducing ability of plasma (FRAP) as a measure of "antioxidant power" the FRAP assay. Anal Biochem, 239, 70-76

31. Khanizadeh S, Tsao R, Rekika D, Yang R, Charles MT, Rupasinghe HPV (2008) Polyphenol composition and total antioxidant capacity of selected apple genotypes for processing. J Food Compos Anal, 21, 396-401

32. SAS (2004) SAS/STAT 9.3 user's guide. SAS Institute Inc, Cary, NC, USA, p 313-383

33. Kroger M, Weaver JC (1973) Confusion about yogurtcompositional and otherwise. J Milk Food Technol, 36, 388-391

34. Wee JH, Park KH (1997) Retardation of kimchi fermentation and growth inhibition of related microorganisms by tea catechins. Korean J Food Sci Technol, 29, 1275-1280

35. Choi OJ, Choi KH (2003) The physicochemical properties of Korean wild teas (green tea, semi-fermented tea, and black tea) according to degree of fermentation.

J Korean Soc Food Sci Nutr, 32, 356-362

36. Davis JG (1970) Laboratory control of yogurt. Dairy ind, $35,139-144$
37. Kim SH (2014) Characteristics of lactic acid fermentation of plum juice by Lactobacillus plantarum KLAB21 possessing antimutagenic effects. MS Thesis, Kyungpook National University, Korea, p 32

38. Bang BH, Park HH (2000) Preparation of yogurt added with green tea and mugwort tea and quality characteristics. J Korean Soc Food Sci Nutr, 29, 854-859

39. Park HJ, Kim SI, Lee YK, Han YS (1994) Effect of green tea on kimchi quality and sensory characteristics. Korean J Food Cook Sci, 10, 315-321

40. Son CW, Shin YM, Shim HJ, Kim MH, Kim MY, Lee KJ, Kim MR (2008) Changes in the quality characteristics and antioxidant activities of yoghurts containing spirulina during storage. J East Asian Soc Dietary Life, 18, 95-103

41. Park GS, Lee SJ (1999) Effects of Job's tears powder and green tea powder on the characteristics of quality of bread. J Korean Soc Food Sci Nutr, 28, 1244-1250

42. Kim SI (2010) Studies on the physicochemical and sensory properties of fresh pork and cooked products prepared with green tea extract. Ph D Thesis, Sejong University, Korea, p 12, p 49-50

43. Cho JY, Jo YL, Son GH, Kim SJ, Ma SJ, Moon JH, Park KH (2014) Manufacture of green tea-Makgeolli and its free radical-scavenging activity. J Kor Tea Soc, 20, $71-76$

44. Lee MJ, Kwon DJ, Park OJ (2007) The comparison of antioxidant capacities and catechin contents of Korean commercial green, oolong, and black teas. Korean J Food Culture, 22, 449-453

45. Hong HJ, Choi JH, Choi KH, Choi SW, Rhee SJ (1999) Quality changes of Sulgiduk added green tea powder during storage. J Korean Soc Food Sci Nutr, 28, 1064-1068 